\title{
Acute-on-chronic mesenteric ischaemia by early and diffuse atherosclerosis in a young adult patient
}

\author{
Marta Gravito-Soares, 1,2 Elisa Gravito-Soares, 1,2 Pedro Figueiredo, ${ }^{1,2}$ Luis Tomé1,2
}

'Department of

Gastroenterology, Centro Hospitalar e Universitário de Coimbra, Coimbra, Portugal ${ }^{2}$ Faculty of Medicine, University of Coimbra, Coimbra, Portugal

\section{Correspondence to Dr Marta Gravito-Soares, ms18498@gmail.com}

Accepted 18 December 2017 CrossMark

To cite: Gravito-Soares M Gravito-Soares E,

Figueiredo $\mathrm{P}$, et al. BMJ Case Rep Published Online First: [please include Day Month Year]. doi:10.1136/bcr-2017223511

\section{DESCRIPTION}

A 48-year-old Caucasian man with gypsy ethnicity had smoking habits (35 pack-years) and previous alcohol consumption ( $10 \mathrm{~g} /$ day; abstinent for 3 years). There was no relevant personal/family cardiovascular disease, history of illicit drug abuse, non-steroidal anti-inflammatory drug use or other previous/current medications. He had a 3-year history of chronic diarrhoea (3-4 bowel movements/day), abdominal pain and weight loss (25.9\% of usual weight; body mass index $=13.7 \mathrm{~kg} / \mathrm{m}^{2}$ ). In the last month, an exacerbation of abdominal pain occurred with excruciating postprandial episodes requiring opioid analgesia. Laboratory analysis showed leucocytosis $\left(34.8 ; \mathrm{N}: 4-11 \times 10^{9} / \mathrm{L}\right)$, neutrophilia (90.6\%), normocytic/normochromic anaemia (haemoglobin: 8.0; N: 13-17g/dL), high Erythrocyte sedimentation rate (ESR) $(54 ; \mathrm{N}<20 \mathrm{~mm} /$ hour), faecal calprotectin $(4890 ; \mathrm{n}<50 \mathrm{mg} / \mathrm{kg})$ and C-reactive protein (CRP) (10.7; $\mathrm{N}<0.5 \mathrm{mg} / \mathrm{dL})$. Oesophagogastroduodenoscopy and ileocolonoscopy with biopsies showed multiple Helicobacter pylori-negative gastroduodenal ulcers (figure 1A,B) and non-specific mild ulceration of the terminal ileum and proximal colon, without granulomas. CT enterography showed distended small bowel loops without parietal thickening/stenosis. Capsule enteroscopy revealed diffuse ulcerative enteropathy (figure 1C). An extensive diagnostic work-up

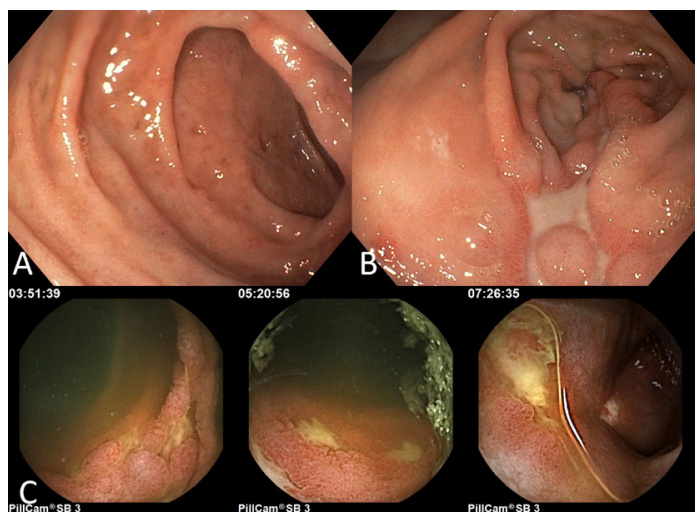

Figure 1 Oesophagogastroduodenoscopy showed a congestive and erosive duodenal mucosa (A) and multiple and extensive ulcers in the distal body and the antrum of the stomach (B). Biopsies of stomach and duodenum revealed unspecific Helicobacter pylori-negative gastroduodenal ulceration without specific features for inflammatory bowel disease as granulomas or other diseases; capsule enteroscopy showing multiple and diffuse ulcers in the entire small bowel, which increase in number and size in the proximal-to-distal direction (C).

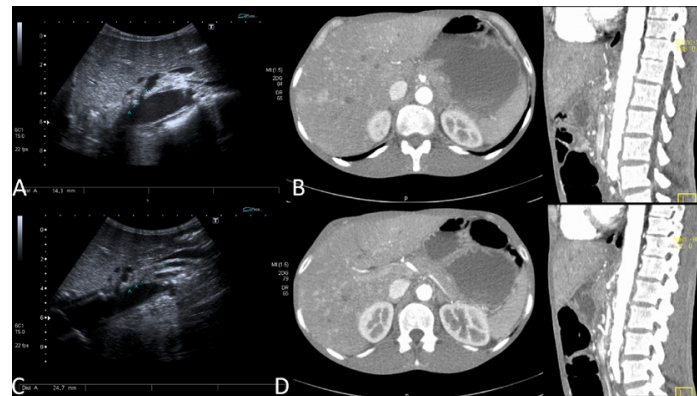

Figure 2 Abdominopelvic Doppler ultrasonography (A) and CT angiography (B) showing a $14 \mathrm{~mm}$ plaque in the emergence of coeliac trunk conditioning haemodynamically significant stenosis; abdominopelvic Doppler ultrasonography (C) and CT angiography (D) showing a $25 \mathrm{~mm}$ plaque in the emergence of the superior mesenteric artery conditioning total occlusion with distal collateral circulation.

for ulcerative enteropathy was negative. Abdominopelvic Doppler ultrasonography/CT angiography showed diffuse atherosclerosis of the abdominal aorta and significant strictures of the emergence of coeliac trunk ( $>90 \%$; figure $2 \mathrm{~A}, \mathrm{~B})$ and superior mesenteric artery (>99\%; figure 2C,D) with distal collateral circulation. There was no significant stenosis of coronary or vertebrocarotid territories and vasculitis signs. Hypercoagulable work-up was remarkable for high lipoprotein (a) $(130 ; \mathrm{N}<30 \mathrm{mg} /$ $\mathrm{dL})$. Angiography of the coeliac trunk with endovascular stent placement was possible despite the total occlusion of the superior mesenteric artery emergence, blocking the guidewire passage. A fast clinical improvement occurred after revascularisation. Atorvastatin, dual antiplatelet therapy (acetylsalicylic acid and clopidogrel) and smoking cessation were started. He remained asymptomatic during the 11-month follow-up.

Although chronic mesenteric ischaemia (CMI) is not uncommon in patients older than 75 years, this condition is underdiagnosed and the diagnosis is often delayed due to the low index of suspicion, especially in young adult patients. ${ }^{1}$ It is generally caused by atherosclerosis, but early and diffuse atherosclerosis conditioning occlusive strictures of major bowel-providing arteries are rare in young adult patients. ${ }^{12}$ Lipoprotein (a) has been associated with early aortic atherosclerosis and its progression. ${ }^{3}$ Endovascular revascularisation is the therapy of choice. ${ }^{2}$ We report the case of an acute-on-CMI of two major bowel-providing arteries (the coeliac trunk and superior mesenteric artery) secondary to early and diffuse atherosclerosis in a young adult 
patient, facilitated by smoking and high lipoprotein (a). We emphasise the importance of keeping in mind an acute-on-CMI diagnosis in a patient with risk factors for atherosclerosis, typical symptoms (chronic diarrhoea, weight loss and severe abdominal

\section{Learning points}

- Although chronic mesenteric ischaemia is not uncommon in patients older than 75 years, this condition is underdiagnosed and the diagnosis is often delayed, especially in young adult patients.

- In a patient with risk factors for atherosclerosis and classic symptoms (chronic diarrhoea, weight loss and severe abdominal pain), right-sided colitis and Helicobacter pylorinegative gastroduodenal ulcers should raise the suspicion for acute-on-chronic mesenteric ischaemia.

- Acute-on-chronic mesenteric ischaemia is a potentially fatal condition. A high index of suspicion, early diagnosis and prompt treatment with intestinal revascularisation are crucial to avoid fulminant bowel necrosis. pain), right-sided colitis and $H$. pylori-negative gastroduodenal ulcers. Early diagnosis and prompt treatment with intestinal revascularisation are crucial to improve prognosis and avoid fulminant bowel necrosis.

Contributors MG-S and EG-S contributed equally, writing the manuscript and reviewing the literature. MG-S is the article guarantor. PF and LT critically reviewed the manuscript.

Competing interests None declared.

Patient consent Obtained.

Provenance and peer review Not commissioned; externally peer reviewed.

(C) BMJ Publishing Group Ltd (unless otherwise stated in the text of the article) 2018. All rights reserved. No commercial use is permitted unless otherwise expressly granted.

\section{REFERENCES}

1 Kärkkäinen JM, Acosta S. Acute mesenteric ischemia (part I) - Incidence, etiologies, and how to improve early diagnosis. Best Pract Res Clin Gastroenterol 2017;31:15-25.

2 Björck M, Koelemay M. Editor's Choice - Management of the Diseases of Mesenteric Arteries and Veins: Clinical Practice Guidelines of the European Society of Vascular Surgery (ESVS). Eur J Vasc Endovasc Surg 2017;53:460-510.

3. Malaguarnera M, Vacante M, Russo C, et al. Lipoprotein(a) in Cardiovascular Diseases. Biomed Res Int 2013;2013:1-9.

Copyright 2017 BMJ Publishing Group. All rights reserved. For permission to reuse any of this content visit http://group.bmj.com/group/rights-licensing/permissions.

BMJ Case Report Fellows may re-use this article for personal use and teaching without any further permission.

Become a Fellow of BMJ Case Reports today and you can:

- Submit as many cases as you like

- Enjoy fast sympathetic peer review and rapid publication of accepted articles

- Access all the published articles

- Re-use any of the published material for personal use and teaching without further permission

For information on Institutional Fellowships contact consortiasales@bmjgroup.com

Visit casereports.bmj.com for more articles like this and to become a Fellow 